\title{
Disney's Violent WOMEN In Quest of a 'Fully Real' Violent Woman in AMERICAN Cinema
}

\begin{abstract}
This paper discusses the violent female characters in the Disney World and argues that although the Disney Studio seems to be a rather unlikely candidate for giving us some of the most memorable and complex violent women in Hollywood, it still seems to be the case. From the Wicked Queen in Snow White and the Seven Dwarfs (1937) to Merida in Brave (2012), Elsa and Anna in Frozen (2013), Maleficent in Maleficent (2014), Judy Hopps and Bellwether in Zootopia (2016) or Moana and Te Fiti in Moana (2016), Disney created 'fully real' violent women who are well-rounded figures, and mostly, but not exclusively, femmes fatales. After definitions of the femme fatale and the discussion of how these violent female characters/Disney femmes fatales were/are represented in the Disney(/Pixar) animated (as well as some live action) films, a cultural-historical overview and analysis follows by focusing on the most outstanding violent woman characters in Disney history from the beginnings up until the latest productions.
\end{abstract}

\section{Key words}

Violent women; femme fatale; Disney princess; American cinema; Disney and Pixar animations

Susan Knobloch when discussing Sharon Stone's violent woman characters drew the conclusion in 2001 that "Hollywood still seems unable to conceive of a violent woman - a functioning fighter, a sexual subject - who is fully 'real"' (140). Although, Knobloch seems to forget about such outstanding and remarkable examples, who refute her stance - Matty in Body Heat (1981), Megan in Blue Steel 
(1989), Bridget in The Last Seduction (1994), Marge in Fargo (1996) or the most iconic film among all: Thelma and Louise (1991) to all of whom the above description applies - hence, her statement could be debated even if we only think about films made before 2001. Yet, some of the recent films prove it even more that there are several 'fully real' violent women in American cinema such as the sex workers in Sin City (2005), almost all of the female characters, especially Luz, in Machete (2010) and Machete Kills (2013), and all of the women, especially Imperator Furiosa, in Mad Max: Fury Road (2015) etc. What does Knobloch exactly have in mind when referring to a fully real violent woman - we might ask? In addition to being "a functioning fighter" and a "sexual subject" (Knobloch 2001: 140), a fully real violent woman also has a mature and complex personality, being a subject in every sense and an agent of her own destiny, she has 'integrity' in a sense that she has an intricate and complicated set of motivations and a history, or rather herstory, to act the way she does. This characterization befits the archetypal figure of the femme fatale, present in both classic and popular literature, the (visual and performative) arts (most notably comics) as well as in cinema. For a short introduction to this figure let me refer to my book entitled Merry Murderers: The Farcical (Re)Figuration of the Femme Fatale in Maurine Dallas Watkins'Chicago (1927) and its Various Adaptations:

The femme fatale is that iconic female image which is connected to the figure of the female transgressor and criminal in literary and filmic works as well as cultural representations. The femme fatale is primarily linked to tragedy and tragic desire and 'her' fall is inevitable traditionally. A prototypical femme fatale is endowed with extremely attractive physicality as well as sharp intelligence. She is generally beautiful, pretty, (often strikingly) clever and intelligent, very deceitful, manipulative, and greatly ambitious. She is usually willing to do anything to achieve her goals and entirely disregards everybody else's interests and feelings. (Toth 2011: 7)

The film industry, with its roots in the Victorian period, builds heavily on the prevalent feminine stereotypes of the latter part of the nineteenth century. The technology of filmmaking was invented in the 1890s and early representations of women were strongly reliant on Victorian ideals of femininity and proper behavior which had (as still have) strong ties with religious values. As Bram Dijkstra opines,

[w]ithin this context the movies' wholesale appropriation of the essential gender dichotomies characteristic of late-nineteenth-century art became a crucial factor in establishing the twentieth century's visual iconography of the 'battle of the sexes' (1996: 313, emphases added).

Dijkstra argues that the gender dichotomies of the nineteenth century, together with the representational logic of the times, prevailed in the twentieth century and asserts that these still affect us through the visual conventions today: 
As a result, even today many of the visual conventions of nineteenth century art appropriated by the silents continue to shape our notions of sexual difference. The movies helped turn the metaphors of fin-de-siècle art and science into the psychological realities of the twentieth-century gender and race prejudice. (1996: 316, emphases added)

Hence, in accordance with the 'Christian-Victorian' concept, a woman had to be a pure lady, the angel in the house (UK) or a true woman (US), and if she failed to display such qualities that presented her as an ideal lady or did not follow the dictates of society she was labeled as a fallen woman, later a femme fatale (when the term came into existence). The angel in the house and the true woman both have strong ties with the "eternal feminine", which means being submissive, modest, self-less, graceful, pure, delicate, civil, compliant, reticent, chaste, affable, polite (Gilbert and Gubar 1980: 23), "slim, pale, passive", snowy and immobile in a porcelain-like manner (Gilbert and Gubar 1980: 25). At the historical beginnings of cinema and the studio system, the then-prevalent, dual feminine types and cultural stereotypes were adapted to the screen: the ingénue (the filmic angel in the house or true woman) and the vamp (the cinematic fallen woman or femme fatale). The term, vamp (the shortened version of vampire) was invented when the femme fatale "reached" the United States, became integrated into the American slang use and was "renamed, reshaped" by Hollywood (Heller 1981: 11). The 'European' femme fatale term was 'Americanized' culturally and the new one was the short and expressive term: vamp. (Toth 2011: 10-16)

According to Robert L. Daniel, the cultural-ideological basis of the "Cult of True Womanhood" and the "Victorian Lady" is rooted in the Judeo-Christian heritage" (1987: 4-5), which evidently involves the roots and background of the counterpart: the fallen woman or the femme fatale, or the even-later-developed term for this type of woman: the vamp. Janey Place also points out that the archetypal violent woman has long enjoyed a central place in the Judeo-Christian heritage: "[ $\mathrm{t}] \mathrm{he}$ dark lady, the spider woman, the evil seductress who tempts man and brings about his destruction is among the oldest themes of art, literature, mythology and religion in Western culture" (1996: 35). Clarice Feinman also emphasized the strong cultural embeddedness of the Madonna-whore dichotomy and called attention to patriarchal logic which created these categories and men who posited themselves as "protectors of the madonna and punishers of the whore" in accordance with their interests (1994: 3-4). Interestingly, Hollywood generally still prefers to hold on to its virgin-whore dichotomy with its post-Production-Code-remnants and stillbeloved melodramatic conventions and resists to resolve or amend it or to create more complex female characters - some excellent exceptions exist nonetheless and their number is growing. Patrick D. Murphy acknowledged the power of this lasting tradition likewise arguing in the mid-1990s that the "virgin/whore" dichotomy is a mainstay of dominant American culture" (1995: 126).

The figure of the femme fatale is scattered all around in Hollywood's past and present, and even though it might seem to be a surprising claim, Disney provided 
us with excellent examples with great enthusiasm. The studio founded by Walt Disney in 1923 has already produced several 'fully real' violent women, animated as well as live action, the apotheosis of which being evidently Frozen (2013) rehabilitating Andersen's iconic Snow Queen and Maleficent (2014) rehabilitating Maleficent from Sleeping Beauty (1959). Frozen (2013) and Maleficent (2014) were the first films in the Disney universe where these iconic evil, wicked and violent women were actually asked what their problem was. The creators of these stories looked behind the supposed wickedness, vileness and violence of these women and gave them the chance to tell 'their own' story or 'their' version of the story. In addition to the 'real femme fatale' Disney female characters, there are several female figures, who although basically represent 'the angel in the house type' femininity, are more violent than we would expect. For example, the 'Good Fairies' (Flora, Fauna and Merryweather) in Sleeping Beauty (1959) are the ones who actually defeat Maleficent while Prince Phillip is only their 'proxy' or rather prosthetic phallic device since it is due to their magic that the prince's sword flies into the dragon(ess)'s heart almost by itself. They just seem to be 'plumpy, cutie grannies', but are, in fact, warrior women. Rebecca-Anne C. Do Rozario calls them "the actual rescuers", she also states that "[t]he fairies ... have the final "word" in this story and that "[ $t]$ he fairies, without any vested, social power, still exert considerable power in the kingdom" (2004: 40). Douglas Brode even states that "[w]ithout a team of capable, clever women [...] Disney's hapless prince would not succeed" (2005: 190). Even though Elizabeth Bell - who discusses Disney femmes fatales, heroines and granny figures likewise - calls these grannies as nonthreatening, post-menopausal women who are the good female characters helping the heroines while the femmes fatales are always the middle-aged, powerful women in their prime who are hard to defeat (1995: 107-124), these wise old women are not that lost, innocent and inconsequential as they first appear. Examples ranging from the Fairy Godmother in Cinderella (1950) through the good fairies of Sleeping Beauty (1959), Grandmother Willow in Pocahontas (1995), the elderly Female Gargoyle in The Hunchback of Notre Dame (1996), Grandmother Fa in Mulan (1998) to Gramma Tala in Moana (2016) justify this claim.

In the following part, I will overview the relevant literature addressing Disney's construction of female characters, especially those whom Bell described as the evil, violent, powerful, potent, and sexual femmes fatales with agency and capability to carry out their plans (1995: 115-118), who seek power, independence, freedom and financial security, but equally importantly are the agents who move the plot forward and make the narrative happen because without their efforts there would not be story. This is especially true for early Disney films such as Snow White and the Seven Dwarfs (1937) where the Wicked Queen is, actually, the 'protagonist' of the story since Snow White does not do much more than singing-cleaning-fainting-sleeping-and-waiting. Jack Zipes similarly argues that this story "has very little to do with the trials and tribulations of the virginal protagonist Snow White, but much more to do with the passionate queen, her stepmother, 
and the queen's struggles with her omniscient and authoritative magic mirror" (2011: 115). Zipes suggests that even the animators preferred to draw the Wicked Queen to Snow White or any other character: "[a]s is well known, the animators of the Disney film preferred to draw the evil queen because she was more real and complex as a woman, more erotic, and driven to desperate acts by her magic mirror" (2011: 115). Voicing similar views and quoting M. Warner, Do Rozario adds that "the animators 'concentrate[ed] with exuberant glee on the towering, taloned, raven-haired wicked stepmother; all Disney's powers of invention failed to save the princess from featureless banality and his heroines from saccharin sentimentality" (Warner 207 quoted in Do Rozario 2004: 44). Regardless of the fact that the femme fatale is generally punished at the end of the stories I agree with Elisabeth Bronfen - who widely researched and analyzed femme fatale figures - suggesting that "her transgressions" stay in our minds and not her erasure or punishment (2004: 113) as well as with Sylvia Harvey, for whom the final punishment simply cannot erase the femme fatale figure's strength, power and the force of the transgressive and subversive acts: "[d]espite the ritual punishment of acts of transgression, the vitality with which these acts are endowed produces an excess of meaning which cannot finally be contained. Narrative resolutions cannot recuperate their subversive significance" (1996: 33). This all is especially relevant concerning Snow White's stepmother since everything that happens in the story is a result of her actions, wishes and desires; and what we remember after the viewing is her striking presence (in purple, claret and gold colors) and deeds, the rest of the characters including Snow White mostly function as 'screen-timefillers' and/or 'bio-decorations'.

Disney himself may have secretly wanted the wicked and sexually-powerful female characters to win as he was not so demure about sexual matters after all as it first seems, it was just the inevitable 'blessing' of the Production Code that turned him into a 'good boy' too, and thus he created the Disney Mystique of asexuality and wholesome family entertainment (Griffin 2000: 3-30). Douglas Brode also argues that Disney, in fact, had a very 'healthy' approach to sexuality that focused on its naturalness devoid of any puritanical vilification or condemnation; and Disney had quite many, especially early works, that were rather risqué bordering on the indecent and, in spite of the Production Code, he still managed to 'pull off' several sensitive issues later on, as well (2005: 113-137). Brode even equates Disney's attempts concerning the representation of sexuality with that of Hugh Hefner: "Disney's aim presaged that of Hugh Hefner: to once and for all end the prevailing culture's limiting and lingering Puritanical attitudes. Particularly important was bringing about an end to the dichotomization of women ..." (2005: 120-121). Brode goes so far as to suggest that Disney, in fact, far surpassed Hugh Hefner "addressing issues involving the emotional, intellectual, and spiritual liberation of women" and was a "predecessor not only to Hefner's call for the sexual liberation of women, but also to the subsequent popularization of women's rights, and the liberation of their souls and psyches as well" (2005: 137). Brode extensively discusses how Disney, even during Production Code 
- but before and after likewise -, propagated not only heterosexual relationship in the idealized forms of innocent courtship, but also sexual intercourse as well as healthy sensuality, and even interracial sexuality and homosexuality (what is more, there was an orgy presented in Fantasia (1940) as well as half-naked men and women - even if in the form of centaurs). In Brode's view, Disney was antisexist, anti-racist and propagated egalitarian ideals in general. (2005: 167-197) Additionally, from the 1990s on, it is evident that Disney (and later Disney/Pixar especially) animated films are full of sexual jokes, probably, for the entertainment of the parents that supposedly watch the films together with their children - Do Rozario calls the 'after The Little Mermaid (1989) Disney animated films' not "family entertainment" but "cross-generational" (2004: 48). For example, in almost all Disney animated films of the 1990s, there is a piece of male underwear shown for various reasons, usually with little hearts for a pattern.

Another film, Mary Poppins (1964), also offers proof that the liberation of women and the propagation of women's rights in Disney productions might seem unusual and surprising but it appears that these are all part of the 'Disney business'. Chris Cuomo argues that feminist issues are discussed and presented in these stories, and even though (for instance) Mary Poppins restores the patriarchal family in the end, she remains an independent, professional woman with feminist leanings (1995: 212-223). In addition, in this film, a suffragette mother proudly sings about the suffrage movement calling themselves soldiers and crusaders also adding: "[t]hough we adore men individually, we agree that, as a group, they are rather stupid" (Stevenson 1964: 9 min). Cuomo claims that "Disney's Mary Poppins exemplifies a kind of feminist hero who lives out ideals of women's equality by being completely assertive and autonomous - a full moral agent" while avoids becoming a typical nurturer and "a sacrificial, self-deprecating mother", additionally, she absolutely evades being "male-defined" (1995: 214-215). Cuomo calls her a liberal feminist with egalitarian values and even some radical feminist criticism is possible to be found (1995: 215). On a similar note, Douglas Brode wholeheartedly aims to prove, with which I agree, that Disney advocated feminist causes and claims that "Disney's attitude toward women emphasizes strength of character in pursuit of excellence and self-fulfilment" (2005: 168). He also states that Disney consistently tried to undermine male superiority in his stories and empowered his heroines (Brode 2005: 176-177), which is absolutely proven by the hordes of failing male figures in the stories. Brode even asserts about Snow White and the Seven Dwarfs (1937) that the two women are not simple cardboard figures, two simple extremes of good or bad, but rather complex entities "of the female principle" (Brode 2005: 179). Although I do not entirely agree with atavistic and essentialist notions of 'female principles', what I found a significant point here is that the two women are not total opposites but somehow the same, complex human beings in different phases and situations of a woman's life.

Elizabeth Bell extensively discusses the different female character types in Disney films and claims that the femme fatale characters - usually stepmother figures or mother substitutes - embody "female wickedness" and are "rendered 
as middle-aged beau[ties] at [their] peak of sexuality and authority" (1995: 108). Holding onto their sexuality as well as the full-bloom of their beauty and attraction these women do not fit the category of the nurturing mother taking care of the heroine, as they do not intend to sacrifice themselves on the altar of marriage or motherhood. Their excessive behavior puts them into direct conflict with "[f]eminine sacrifice and nurturing [that] is drawn in pear-shaped, old women past menopause, spry and comical, as the good fairies, godmothers, and servants in the tales" (1995: 108). I agree with Bell that Disney's evil women - the beautiful witches, queens, and stepmothers - are defined as femme fatale and vamp characters through this dichotomy and also believe that their being represented as such gives rise not only to fear and disdain but also fascination towards them. In a conscious act of construction they are portrayed to look like the great "divas" of their era(s) with "exaggerated movements of the hips and arms, with the head thrown back, her [their] hair suddenly spilling down her [their] back, contortions, rolling eyes" (Sadoul quoted in Doane 124-125 quoted in Bell 1995: 115). She claims that "the readibility" of these femme fatale figures is "painted in beautiful and shapely strokes on the bodies of Disney's Wicked Queen, Lady Trumain, Maleficent and Ursula" and "is evident in the careful cosmetics of paint, cowls, jewelry, and "clinging black dresses"” (Bell 1995: 115). That these evil and violent women are considered to be beautiful is also supported by such claims that, for example, the Wicked Queen has a "lovely cruel mouth" (Bell 1995: 116) or that "the production notes describe her 'beauty [as] sinister, mature, plenty of curves"' (Finch 66 quoted in Bell 1995: 116). Hence, these violent female characters are consciously depicted as appealing and attractive which obviously points towards a positive representation and a tendency to praise and possibly support them.

The violence and the 'bad girl' image of femmes fatales are constructed through antagonisms such as power/powerlessness, authority/subjugation, sexual subjects with agency/objects without agency and they are always on the 'winning side' of these antagonisms. Furthermore their wickedness is visually rendered by extreme close-ups, frames in which they "address the camera directly, both advancing the narrative diegesis and confronting the spectator's gaze with their own" (Bell 1995: 116). This is actually in accordance with William Rothman's arguments about virtue and villainy in (American) cinema - the evil ones are the ones who face the camera and confront us with their gaze while the innocent ones never look into the camera, and the case is similar with close-ups as well (2004: 74-86). Their direct look at us and the 'permission' to look at them closely also suggest courage because they dare risk such a proximity and possible 'intimacy'. Bell additionally describes a Disney technique for the wicked women: fading the face and the background into black while highlighting the eyes, which are usually "painted as gold, glowing orbs, narrowing tightly on the intended victim/heroine," this also evokes "primal fears and animal phobias, transforming their faces to the exterior icons of wolves and cats whose eyes glow in the dark" (1995: 117). Additionally, these violent and evil women are usually drawn in a way to evoke 
predatory animals with their body movements and posture to heighten their powers and danger (Bell 1995: 117).

Other layers of the dichotomy are generational and gender-based. On the one hand, the powerful and dangerous female characters ("Disney's deadly women" - as Bell calls them (1995: 117)) at the prime of their sexual powers usually pursue and victimize younger, inexperienced women to annihilate the potential competitors. On the other hand, the kings and male leaders are usually portrayed as "physically and symbolically impotent in contrast to the evil women's sexual potency and powers" (Bell 1995: 117), hence they are not sought as sexual partners by the femmes fatales since they are not 'worth their effort'; or in some cases, for example, Snow White and the Seven Dwarfs (1937) or Cinderella (1950), the father figure was married by the femme fatale figure for money and power, and already by the beginning of the story they are 'done with'. Thus, the Disney femmes fatales are against "the entire society from which they are excluded" and "their excess of sexuality and agency is drawn as evil" (Bell 1995: 117) because it is so overwhelming that no one or nothing can contain it. Disney femmes fatales are pictured as evil and dangerous through the power they exercise over characters of both the same and the opposite sex, yet, and equally importantly, their threat and prowess is also underlined by the communal effort required to defeat them: in the films, there is never a potent and strong alternative figure, male or female, animal, animate or inanimate object or magical creature who could overcome the femme fatale of the story alone. Based on the above features Bell draws the following conclusion about the gender politics of Disney cartoons: "[t]he wicked women harbor depths of power that are ultimately unknowable but bespeak a cultural trepidation for unchecked femininity. That Disney artists resorted to coded cinematic representations of the femme fatale for feminine agency speaks to the lack of conventions for encompassing such incomprehensible power" (1995: 121, emphases added).

Not every scholar shares this view. Emma Bálint, for one, follows that path of Disney criticism, which actually allies her with those feminist authors who regard the representation of women (especially) in early Disney films rather one-sided and stereotypical. As a summary of their arguments, let me quote Bálint:

None of these stories seem to be authentic representation of women; they rather depict issues of male domination and images of male heroism characteristic of the given period. As a result, even the strong women characters in the animations created by Disney during the studio era fall back into the category of the stereotyped ones with the figures accepting their passive, submissive roles, all nested in the heteronormative, male-dominated milieu of the era. (2013)

Bálint also adds that only the male characters have the opportunity to improve themselves and achieve something in life while the women are passive 'drifters' with no aim or purpose, only to be attached to a male, with which I do not 
agree since neither the mature/middle-aged (femme fatale) female figures, nor the 'granny' characters aim to 'mate' with any man whatsoever while they pursue aims that point beyond a familial bond. These women are never passive and submissive, what is more, they always challenge the dictates and rules of the heteronormative-patriarchal system - the femmes fatales openly and aggressively, while the grannies in a subversive, funny way. Additionally, the male characters do not improve either, most of the time, they do not develop during the course of the events, or quite often they do not even do or say anything during the (early) films, and to call anything they eventually do 'heroic actions' is an exaggeration. Nevertheless Bálint goes on:

Even more, Disney's female characters are generally simply thrust into a strict and seemingly unchangeable patriarchal realm, where the notions of meritocracy (for men) and fate (for women) are of utmost importance, a celluloid world where women, even as main characters of the filmic narrative, are mere exhibitionists without distinctive personalities and goals of their own. (2013)

However, the wicked, evil and violent female characters all have striking personalities, clear-cut aims, purposes and goals in life and they do everything in their power, which is not insignificant, to achieve their goals. Although it is true that these femme fatale characters usually cannot reach their aims or goals due to a communal effort to stop them and they cannot be victorious in the end, yet it is not because they are passive women without capabilities, 'ladies-in-waiting', but because everybody is against them. They try to change the patriarchal realm, and although being defeated themselves, ironically, they still create changes. In my view, the Disney femmes fatales' revolt against the patriarchal order fails not because of their wickedness, but due to the Studio's concern for the Production Code(s), the transgression of which would have easily knocked them out of business. Beneath the saccharine coating of conservative morality suitable for family entertainment, there is a genuine fascination for, what Bálint also acknowledges, the femme fatale characters' power, and capability for subversion: "the most wicked woman was her stepmother, who is "not only [...] evil but also [represents] erotic and subversive forces' (Zipes 205)" (2013).

Yet again, Bálint turns back to her basic argument stating that the whole story of Snow White is told from the point of view of the Prince, the male hero, who saves the day. However, in my reading of the Disney Snow White story, the Queen's point of view is more dominant than that of the Prince, whose presence is little more than being a catalyst in the whole chain of action. The Prince appears only at the beginning for a brief period of time, falls in love (at first sight) with Snow White (about whom he knows nothing), sings for a few minutes with her, then reappears only right at the end kissing a 'dead girl' (suggesting necrophilia), and after the revival he carries her off to his castle - all this could hardly be called heroic or a significant contribution to any story. Similarly to the other early Prince 
characters, he is much more a 'trophy husband' that the Disney Princesses earn for their submissive, good behavior than actual heroes - with whom the Princesses can continue their submissive, good behavior.

As opposed to this, the Wicked Queen rules as an independent woman without a husband or any strong male figure around her. The lack of a male authority figure is a significant one, and the huntsman (the only actual male in the story) is rather impotent and frail: portrayed as a servant, who is enchanted and awed by the domineering queen as well as feeling sorry for Snow White. He is incapable of any (significant) action in effect. The supposed King (Snow White's father) is already dead by the beginning of the Disney version of the story, the Prince can hardly been posited as an authoritative figure, and the dwarves are depicted as troublesome children who have to ordered about to wash and Snow White has to clean after them as well as cook for them. In addition, they cannot defend her against the Queen. Hence, the only authority figure is the Wicked Queen, who rules alone and there is nobody to equal her in any capacity. Her only flaw is that she still believes that feminine beauty is the most important thing a woman can achieve and she believes the manipulative (male) Mirror (possibly the voice of patriarchy) that bodily perfection is/should be her ultimate goal in life. Additionally, she is very mistaken in that aspect too that she never actually looks at herself in the mirror but only believes the Mirror's opinion - if she ever actually looked at herself she would have realized how beautiful she is. This otherwise very clever and capable woman is simply deceived by another person's failed opinion and looks for reassurance through somebody else's acknowledgement and by trying to defeat other women in the contest instead of relying on her own assessment of her own beauty and value. I agree with Jack Zipes when suggesting that the Queen simply should have broken the mirror and throw it out with its value judgment and interpretations: if she "doubted and cracked the mirror, cracked the meaning of the mirror, she might still be alive today" (Zipes 2011: 115).

Thus, without anybody to stop her, the Wicked Queen (seemingly) proceeds towards victory. Actually, this is the case since she causes her own demise. She orchestrates her own defeat, a failure to gain eternal beauty (which, in itself, is a failed purpose). Her desperate and extreme actions do not grant her the thing she desired most as her inner wickedness literally manifests itself on her body when she transforms herself into the evil, grotesque, abject hag: a physical appearance from which there is no turning back in the story. Had she succeeded in achieving eternal and uncontested beauty, would the situation be different? I am afraid not, since she would only have brought to success and, thus, strengthen male notions of beauty: an aspect of the patriarchy she never really resists or subverts. Having said that however one cannot deny that the Wicked Queen has a true, distinctive and unique personality of her own, the effective imprint of which remains burnt into our brains even after her visual disappearance into the abyss of patriarchy's mountains into which she allegorically falls at the end of the film. Those who found her presence empowering watch her demise with a possible grin on their faces, a very different one from that of the two vultures 
who are overcome by excitement before they dive to decipher the carcass. Their self-content smile is no less allegorical and might manifest the unconscious wish of the (patriarchal) viewer to see the transgressive female characters fail. These women - even though not being passive and submissive, typical women who accept the workings of life, but being figures who initiate change -, by failing in the end, they still ironically contribute to the advancement of the (early) heroines (too), who are usually the 'bovine' and 'somnabulisitc' females that comply with the demands of patriarchy concerning women.

The femme fatale figures in Disney productions are paradoxical: they are always defeated yet returning, and in their reappearances might manifest the repressed fears of the patriarchal order. In addition, the femme fatale characteristics of Disney's female antiheroes gradually 'infect' the protagonists, as audiences recognize, as Amy M. Davis notes, that the villainesses have significant agency and they try to "control not only their lives but also their circumstances" (2012: 107). What is even more, she declares that the destruction of these women is often the result of their own actions (2012: 107), which, on the one hand, seems to lessen their capabilities, but on the other hand, highlights that nobody else would be able to defeat them (alone) if these evil women did not fail themselves. Additionally, Davis concretely calls these women "strong, fearless, and often creative ... mature, powerful, and independent", and eventually hails them stating that the "wicked women, ... the bitches, ... are the strong, active, no-nonsense people who stop at nothing to get things done" even if what they "want to 'get done' are not very nice" (2012: 107). According to Davis, this infectious effect of the wicked women is most prevalent in the animated and live action films made in the period 1989-2005: "[i]t is not just the ways the stories are told in these films, however, but also that the stories themselves, containing as they all do strong, independent, intelligent female characters, are potentially indicative of just how much feminist ideology had entered into mainstream American middle-class values." (Davis 2012: 175, emphases added)

We can clearly ascertain this by 2017 , as these claims are even more valid concerning the recent Disney films that were made after the great success and 'breakthrough' of Brave (2012) and Frozen (2013) since by now, that a woman can be aggressive, assertive and confident while pursuing any aim that does not primarily involve a man or a potential marriage is a staple element in Disney stories. As an example, in Big Hero 6 (2014), we have female superheroes (as well): even though Go Go is a welcome addition to the line of Disney violent women - and might potentially presumed to be a lesbian - since she is an intelligent, independent, no-nonsense person, who does not display any (traditionally-hailed) feminine charm or mannerisms, not even her clothes indicate any femininity as she is visually presented as a tomboy. However, Honey Lemon appears to be a slight failure and an overdone compensation for Go Go being called as well as looking and behaving like a Playboy Bunny at least or a porn star at worst wearing platform boots with mini skirt, or other rather revealing, extremely-feminized clothes and accessories paired with 'mentally-challenged' traditionally-feminine 
forms of behavior such as 'silly giggling' and wide-eyed as well as child-like outbursts of joy etc., which are all doubly harmful considering that she is supposedly a scientist and an inventor - women in science and Academia 'wear sensible shoes' and clothes exactly because they use their brains.

Another important, recent example for how feminist ideology has been embedded within mainstream American middle-class values by now might be Zootopia (2016), in which a policewoman called Judy Hopps (additionally a white, fluffy bunny who overcame all prejudice against her while pursuing her dream and career) is shown in action during the animated film, which evidently involves constant violent action and danger while she solves all problems as well as crimes with the help of her wits being throughout a real professional. In addition, the (interim) mayor of a great city, a metropolis (even almost a city state), becomes another tiny, white and fluffy female animal: an ewe named Bellwether. Nevertheless, the great twist occurs when this 'sheepish lady', who is seemingly the perfect democratic leader, turns out to be 'an evil femme fatale' and the real antagonist of the entire story being a liar, a manipulator, a 'maffia Don' and a criminal mastermind. For all this, she gets punished while Judy Hopps becomes the ultimate hero. It was a quite excellent idea how to adapt the basic ingénue-femme fatale duality of early film history to current problems in society and how to reinterpret the fight of a powerful (supposedly older) woman and a (younger) one in a 'subdued' position of early Disney into the everyday realities of our lives. Since now, a supposedly democratically-elected female leader (here only appointed in a state of emergency) might/could act the same way as a queen did in previous times. Additionally, the female characters themselves become a bit more layered and complex as it turns out that Ms Bellwether is not a simple, cutie lady but she is shaded and complicated, just as well, even though Ms Hopps is 'the good girl' she is a policewoman, who occasionally has to act violently, but by all means, her job involves the negation of all traditionally-conceived ladylike behavior.

The latest Disney Princess production, Moana (2016), also has to be mentioned in connection with the integration of feminist ideology into mainstream American values and thinking, as it was suggested by Davis, because Moana is treated undoubtedly as the future chief and leader of her community, no husband is looked for her to ally the tribe in matrimonial bonds with another 'kingdom or royal line' putting her in the position of 'prize and guarantee' of an agreement. She is always presented as a considerate, wise and democratic leader (in training) while her people, including the men, look to her for guidance accepting her decisions and advice. Additionally, she is often seen in strenuous physical activity, dangerous situations and fights, she generally solves problems through real courage, grit and intellectual as well as physical acuity and strength. In the end, she herself (and alone) - instead of the male demi-god who stole Te Fiti's heart - faces the great and evil, lava monster, Te Kā, who turns out to be Te Fiti herself and by restoring her heart the Goddess turns back into her original self and restores life and peace everywhere. In the meantime, the murderous and undefeatable violent woman (who became such as a result of harm done against 
her and ensuing anger and desperation) disappears in the wind while the fire and lava turns into ashes. It is a fascinating climatic scene when Moana realizing that the raging lava monster is actually the Goddess of Life and Creation-turned evil through betrayal tells the ocean to let Te Kă come to her. While the raging violent woman is rushing towards her, Moana is calmly walking towards her [Te Kā] singing that she [Moana] voyaged so far to meet her [Te Kā/Te Fiti] and restore her while she [Moana] knows that Te Kā is also aware that she is actually Te Fiti and should act so. These women find themselves through each other and with each other's support, not through men, who mostly only cause the hardships and problems instead of solving them. As the grandmother (and not the father or any male figure) helped Moana understand who she is, Moana, in turn, helps Te $\mathrm{K} \bar{a} / \mathrm{Te}$ Fiti to find herself. The younger woman thus restores the 'older' (actually timeless and eternal) woman's identity and self through trust and love while also braving all kinds of perils. Eventually, her choice of future is granted to her people as her father (the current leader) follows her lead by setting sail and starting voyaging again all over the oceans.

These latest examples are especially interesting and important because the children who were born after 2010 will encounter these heroines first when they start their visual journeys and their role models will be girls and young women who take it for granted that they can be leaders, professionals in any field, and that they can study whatever they want to. Our daughters get the message that they do not have to sit demurely embroidering all day long or clean happily singing and dancing on tiptoes (as early Disney Princesses always did) but they can fight, jump, run, kick and punch. They are told that they have the right to have an opinion and say it while not being hushed. And most of all, they are taught that they are not dependent on any man for survival but they can be free and independent agents of their own fate. These recent female characters do not try to find themselves and their destinies through men, their task is not to find love (exclusively) and get married while fighting other females in a beauty contest for the approval of men. The recent Disney/Pixar women do not expect the answers to their questions from men but they themselves set out to find those answers and attempt to achieve self-definition through and with the help of other women. These latest Disney women learned from the 'earlier' violent women and femmes fatales how to be free and independent through self-definition, self-sufficiency and self-reliance even though these early women who attempted that were usually crushed. The 'sacrifice' of these very women contributed to the current 'liberation' of Disney heroines analogous to what Sally Ledger claimed about the New Woman fiction citing from The Daughters of Danaus:

"Hadria ... recalled a strange and grotesque vision, or walking dream, that she had dreamt a few nights before: of a vast abyss, black and silent, which had to be filled with the bodies of women, hurled down to the depths of the pit of darkness, in order that the survivors might, at last, walk over in safety. (Caird 1894: 451 quoted in Ledger 29-30) 
Even though this is not such a happy vision, this is what happened to the early violent women and made it possible that today we have Disney heroines or rather female heroes who can be the violent women walking with their heads high up, and even with female solidarity included. That feminist ideology has already been ingrained into mainstream American values and thinking is proven by their presence, actions and words.

Davis named the period between 1989-2005 as the starting point, which seems to be quite convincing since the 1990s was of utmost importance in the development of Disney heroines on their way to become autonomous and independent characters, yet during this period of time, they still did not manage to carry out this task thoroughly always ending their stories with a man within the walls of a home giving up professional dreams. The real transformation became accentuated and really prevalent in contemporary Disney(/Pixar) films starting with Brave (2012) and Frozen (2013), in which the Princess character really became a "Tough Gal" (Davis 2012: 175) pursuing aims that involve character development as well as providing a professional fulfilment while excluding matrimonial bondages as imperatives. Certainly, as it has been mentioned such a "radical departure" (Davis 2012: 175) would not have been possible without the emerging positive stereotypes of the autonomous woman as well as the major changes that occurred in the representation of women during the 1990s - without which we would not have Meridas (and her mother, Queen Elinor) or Elsas and Annas (these characters will be discussed in more detail later).

Another significant aspect of this trend is the underrepresentation, or much rather, lack of powerful male figures: instead of strong fathers and kings, the films feature defective, impotent and weak, male parents, who are incapable of defending their daughters, people and kingdom from the potent, wicked and violent women - despite the fact that 'Disney' still mostly stands for a paternal and "aggressively patriarchal" world (Do Rozario 2004: 34-35, 43). This is the main reason why the dramatic tension lied/lies between women, and the female conflict often develops into a lethal rivalry. As Rebecca-Anne C. Do Rozario declares: "[k]ings are powerless, almost irrelevant, when faced with the femme fatales" (2004: 43) also adding that "male power is reduced or erased, [... and] the greatest tension is created between women" (2004: 42), while eventually these stories turn out to be "tales of female conflict" (2004: 39). Do Rozario also adds that, especially in early Disney animations, "the circumstances empowered the femme fatales: rulers of men and queens of their own domain" (2004: 36). Emma Bálint also cites Michael Barrier concerning the relationship between Snow White and the Wicked Queen as an example stating that there was a "lethal rivalry between Snow White and the queen" (Barrier 102 quoted in Bálint 2013). Amy M. Davis is also of the opinion that, in Disney films, the focus is on the "rivalry between an older woman and a younger heroine" and that this older woman usually sees the younger woman as a "threat," that is why the femme fatale figure reacts to the ingénue character with "obsessiveness akin to madness" (2012: 108-109). 
Another explanation for this type of conflict to predominate the Disney animated films is that women are rarely blood relatives, in fact biological mothers are almost non-existent, and even if being alive they are ineffectual, while parents in general are either "absent" or weak", but by all means "powerless" - which is actually in accordance with the "folk and fairy tale tradition" (Davis 2012: 102-103). Emma Bálint also argues that "truly caring mothers rarely appeared in Disney productions then or even today" (2013). This absence is a conscious element of the psychodynamics of the plots, since it is the missing mother, her lack, that induces the personality development of the child and, as Davis claims, "the lack of a strong parent" forces the protagonist to mature and become an "independent adult" (2012: 102). We might even refer to Bruno Bettelheim (whose argumentation is cited by Sarah Boxer discussing missing mothers in cartoons and animated films in general) who argues that the death of the good mother and her substitution with an evil stepmother in fairy tales is a tool for helping the child to solve his/her conflicts with his/her real mother who is obviously not 'perfect, sweet and ideal' all the time (Boxer 2014).

Nonetheless, what is even more interesting and important in what Do Rozario argues for is that the Disney Princess herself started to turn into a femme fatalish character, a more complex female character eliminating the more circumscribed (negative) violent female characters of early Disney (2004: 44-57). It is Ursula in The Little Mermaid (1989) who is the last 'classical' Disney femme fatale, or rather a grotesque, carnivalesque caricature of it, while Ariel - whom she teaches the "femme fatale's trade", - clearly marks a transitional period in the representation of socially acceptable femininity (Do Rozario 2004: 44-45). Amy M. Davis also agrees that Ariel "clearly [was] differentiated from earlier Disney princesses" (2012: 177) and started the new tradition of 'spunky heroines', who are sexual, confident, active, independent, strong-willed, self-reliant, rebellious, combative, and intelligent, in addition, "when the chips are down, they go out and do what they must, and do not sit and wait to be rescued", sometimes or rather more and more, even they are the ones who do the rescuing (Davis 2012: 225). As the character of Belle in Beauty and the Beast (1991), Pocahontas in Pocahontas (1995), Esmeralda in The Hunchback of Notre Dame (1996) or Mulan in Mulan (1998) prove, from the 1990s on, the heroines are complex figures, no longer living in the shadow of a strictly negative and evil, elder, other woman. I would also add that this tendency was already prevalent in One Hundred and One Dalmatians (1961) where Cruella De Vil was a rather grotesque caricature of the femme fatale likewise who, by the way, escaped punishment, although she did not get what she wanted either. This film is also exceptional for presenting healthy, strong and kind mother figures, while Perdita is also a fighter and saves her puppies together with Pongo.

According to Do Rozario, 'Team Disney Princesses' (who came after the death of Walt Disney) became sportswomen (2004: 46) while "[h]eroism, egalitarianism and autonomy" became included into their princesshood (2004: 47). Additionally, while in the past, femme fatale characters were the ones who disrupted 
the patriarchy, today, it is the Disney Princess herself, or rather the Disney Heroine (since these new type of princesses are not always of royal blood or are real princesses and there are also non-princess heroines) who alters and reconfigures it or, as Do Rozario points out, make the kingdom a livable place by being "progressively proactive" (2004: 57) while daring to learn the "dirty dance" and investigate what is "beyond the father's rule" (2004: 50-51). They make their own choices in life that often affect other people, even an entire kingdom, but they always prove to be wise and good rulers who make good, often better, decisions than their fathers. I agree with Do Rozario's closing remark: "[t]he Disney kingdom may still seem a man's world, but it is a man's world dependent on a princess" (2004: 57).

In the final part of my paper, after theorizing the historical trajectory, I continue analyzing the femme fatale figures and the violent women through notable characters of Disney productions (I will discuss only some major examples since the scope of this paper cannot cover all Disney/Pixar animated films). The prototype of the violent femmes fatales is obviously the Wicked Queen in Snow White and the Seven Dwarfs (1937) within the Disney oeuvre. As it has been mentioned she is the protagonist of the story who wants, thinks and acts. She is a powerful female figure who married a man for money and power - who does not even appear in the story - and she rules the kingdom alone. She acts out her hunger for acknowledgement through her maniac pursuit of beauty. She is a mature beauty, not the fragile young flower like Snow White, and throughout the story, her rival in not really the tender princess but much rather the mirror, which tries to teach her that true beauty is an inner quality. The Queen falls victim of her own vanity as well as the Production Code during which it was expected that wicked characters get what they deserve. She exemplifies the strong woman, whose feminine self is reliant on being beautiful and whose rationality, capabilities and consistent planning are all subordinated to finding the perfect look, the 'Image' of physical perfection.

My next example is again an evil stepmother: Cinderella's stepmother, Lady Tremaine, and her two stepsisters: Anastasia and Drizella in Cinderella (1950). They are not warrior women who openly try to kill her, yet, they make the protagonist's life miserable every day. In this case, it is jealousy, mistrust, and hatred - basic human emotions and personality traits - that motivate their behavior. The type of violence they commit against Cinderella, tearing up her dress for example, is humiliation targeting beauty, one's physical perfection. In addition, the stepmother is a woman who married for money and a social position while the husband is again missing. She is much more cunning and manipulative than the Wicked Queen and works in much more silent and invisible ways, making her treachery and slyness quite more dangerous. Cinderella is the first Disney animation to feature the Fairy Godmother type - who (seemingly) befits patriarchal notions of elder ladies -, and as a prototype of all assertive 'granny figures', comes to the aid of Cinderella. It is also well-known that even though Cinderella is the protagonist, the animal helpers get much more screen time than any human and 
Cinderella does not much more than be good, enduring, beautiful and 'perfect' all the time. Whatever happens in the story is again induced by the actions and wishes of the violent woman, Lady Tremaine, who is visually associated with her black cat called Lucifer. She is physically not repulsive and could be conceived as a mature beauty herself while her daughters are clearly caricatures and visually presented as grotesque. The Prince does and says even less than in Snow White and the Seven Dwarfs (1937) and the King is entirely ineffective and ridiculous. Thus, it is again much rather the evil woman's story than anybody else's. Nevertheless, evil is punished and virtue is victorious in accordance with the regulations of the Production Code.

Maleficent in Sleeping Beauty (1959) diverts from those 'femme fatale heroines', whose determination and resourcefulness stems from an almost manic desire for a perfect body or for the winning of the attention of a man through beauty, as Maleficent is not obsessing about her beauty, she is much more concerned about power and domination. In fact, she is one of the first really powerful and dangerous evil, female characters whose intelligence is coupled with a willingness to use physical violence (even if in the form of magic). In the final battle scene of the film, Maleficent is defeated by the good fairies and not a prince or a king. She is a strong and angry woman impossible to be tamed or subdued; and whose anger, according to the story, was provoked by not having been invited to the party of the newborn princess. The deeper causes of such a psychopathic behavior are tackled in Maleficent (2014) which tells the story of her traumas and the real reasons for her desperate rage and hatred, and again in Frozen (2013) - where the nature of Elza's distress is examined in a similar vein. It is very important that the creators wanted to explore her character and as such went beyond the stereotypical depictions of the femme fatale and made her wickedness real by exposing the real reasons of her behavior, such as being mutilated and betrayed by her love in her youth, who gained power and money in the form of a 'trophy kingdom with a princess for a wife' as a reward for this deplorable act. Another significant 'invention' is that Maleficent herself becomes the mother substitute of Aurora (the daughter of her ex-lover in her youth who betrayed her), and Maleficent herself will be the key to breaking the spell that she cast (and seemingly cannot undo) by choosing love and granting the 'famous true love's kiss' that is usually the task of the rescuing prince waking Aurora. This very same logic works in Frozen (2013) too where the 'supposedly evil female character', Elza, cannot undo the curse and through an 'act of true love' Anna (her sister) saves Elza (and at the same time herself), not a prince, while with the help of love Elza also succeeds in curbing the curse and learns to manage her powers.

Cruella de Vil in One Hundred and One Dalmatians (1961) is the first one among the 'classic' Disney violent females who is not punished for her actions, which yet again are connected to appearance and the 'Perfect Image', embodied in the form of the much-desired fur coat that should have been made from the skin of puppy Dalmatians. Cruella is visually represented in dual black and white colors as if suggesting schizophrenia and mental illness (with her swirling eyes towards 
the end likewise), additionally, to heighten her 'sickness' she is also drawn as an anorexic person and her hand is sometimes drawn in a way to allude to a spider. She is not depicted as beautiful but her desire is to become a beauty through consumer goods, clothes and accessories, hence, her artificiality is also emphasized. This story is also driven by the violent woman's will and actions. However, as it has already been mentioned, for the first time, in the figure of Perdita, we have a strong, complex, positive, and most of all, living mother figure, who not only gives birth to, cares for and nurtures her 'babies' but adopts several other puppies, and in the meantime, she does not shy away from marching through an entire country in a hailstorm and fight, bite and snarl when she has to in combat.

The Little Mermaid (1989) was the last Disney animated film with a 'classical' femme fatale character, although a somewhat carnivalesque version and a travesty of the 'old-school' Disney villainess. Ursula, the octopus with magical powers, is a powerful, adept, and professional conspirator and a witch, who wants to take revenge on Triton (for not clearly explained disagreements in the past) and get his crown. Ursula is not against Ariel but Triton and wants to defeat him - she is after power and dominion. This was the first animated film where the wicked femme fatale character comes face to face with a rather 'spunky' young heroine, who also possesses the character-traits of a strong-minded woman. Nevertheless, Ursula, even though looking like a transvestite, is very sure of herself (as a woman), her powers, and even her 'feminine' allure teaching Ariel how to behave and act like a woman (in an attempt to seduce a man). This especially highlights the performativity of gender and how artificial it is to repeat the socially-constructed signs of a supposedly desirable 'biological woman', in order to perform the (image of a) socially-accepted woman. Her cave even looks like a womb and when Ariel enters, Ursula descends from a sea shell that looks like the opening of a vagina. In this animated film, it is Ariel whose desire and actions drive the story, the violent woman character only manipulates and tries to thwart it. As Do Rozario has suggested, here the Disney Princess starts to become the violent woman and takes charge. Ariel is not a passive figure any more but an adventurer and a 'scholar', who wants to explore, learn and experience beyond the known and knowable. However, the evil woman is defeated and the Disney Princess still gets reconciled with marriage and a castle.

An interesting addition to the examination of these female characters is the film entitled Who Framed Roger Rabbit (1988). This work is a mixed live action and animated film, a Touchstone product, which means that it is not Disney with its famous signature, yet, it is part of the Walt Disney Studios, hence a Disney product. In this film, Jessica Rabbit takes after the prototypical film noir femme fatale in an animated form. It is hilarious how this archetype is 'Disneyfied', and made to look like a cruel and evil woman capable of doing anything, while in fact, she turns out to be a gold-hearted woman who strays a little, and claims at one point with a pun that "I am not bad, I am just drawn that way" (Zemeckis 1988: 47 mins). She is the perfect manifestation of the film noir or rather neo-noir femme fatale, while the animated film itself is also an excellent example of neo-noir or a remade film noir. 
From this time on, the heroines themselves are young and complex women who do not shy away from using their brains, knowledge, expertise, and are not afraid to fight back. Belle in Beauty and the Beast (1991) is, actually, a brave young woman who rather than being afraid of the beast 'tames' him slowly, like a 'lion tamer'. She stands up to both violent men actually: Gaston as well as the Beast. It applies to both men what Allison Craven suggests (based on Elizabeth Dodson Gray) that these men have "the "psychological profile ... of a violence prone wife batterer"' (Gray 1992: 159 quoted in Craven 2002: 133), but Belle does not let herself be intimidated and puts both men in their places. She even tries to fight the wolves, though, without the help of the Beast she probably would not have won. Nevertheless, she is knowledgeable, inquisitive, adventurous, free and independent. She wants to know more about the world than the rest of her surroundings and sets out on her journey of discovery, however in the end, similarly to Ariel, she also gives up all her 'unwomanly' dreams of knowledge and discovery for the love of a man and the security of a castle. Craven argues that Belle's "feistiness" - a certain kind of "graceful, perky, fighting spirit" - became a trademark of Disney heroines from this time on as a sign of "consumer feminism" (2002: $127,129)$ because Belle is only considered to be a "pro-feminist girl" (2002: 139). Craven suggests, based on Marina Warner, that this "film placed before the 1990s audience Hollywood's cunning domestication of feminism itself" (Warner 1994: 313 quoted in Craven 2002: 124). An interesting addition considering the visual depiction of the female protagonist is that she is a 'mousy' brunette with hazel eyes, not a striking blonde with sparkling blue eyes or being a spectacular redhead. Finally, for the first time, we have the representative of an 'average woman', probably the majority of women, in the figure of Belle.

In Pocahontas (1995), Pocahontas is already posited as a future leader who is strong in every sense of the word and is taught traditional wisdom by a 'granny figure', Grandmother Willow. Even though, Pocahontas is a quite empowering character as well as story, unfortunately, it is a crude distortion of reality and history against which the members and representatives of the American Indian Movement protested (Edwards 1999: 160, 147-162). Despite all this, this story provides us with the first love relationship that does not end in marriage and Pocahontas stays back in the New World, probably, to become the next leader of her people. She is brave, athletic, wise and democratic making better decisions concerning the lives of her people than her father, the current leader. She is the first Disney Princess who is constantly shown in strenuous physical activity, climbing trees, jumping off cliffs, running free in the woods, canoeing and rafting etc. She is a free and independent agent of her own life and a wise guardian of her tribe's future.

The Esmeralda of The Hunchback of Notre Dame (1996) is a very clever, athletic, brave, defiant, and fierce person, who even pole-dances during the carnival scene. The most outspoken expression of her sexuality however appears in the fantasy of Frollo, in which Esmeralda appears in flames and acts as a seductress - according to the pattern of a rapist's victim-blaming logic. However, in 'real 
life' she is not to be tamed and never yields to immoral causes. Interestingly, her emerald green eyes (the meaning of her name) and black hair are reproduced in Mulan's horse and in Bolt's cat partner, Mittens, in later productions - the combination of raven black hair and green eyes are traditionally indicative of evil, however, in all of these cases, the characters are/turn out to be positive figures. Additionally, here, we have another significant granny figure in the form of the elderly female Gargoyle, who actually initiates Quasimodo's (the first major Disney protagonist with a disability) entrance into the world outside and ignites the chain of events that culminates in Frollo's fall and the victory of the 'underdogs'.

In Hercules (1997), there is Meg, who is again the gold-hearted girl whose life got derailed due to unwise decisions turning her into the bitter and sarcastic helper of Hades, the main evil character of the film. She is depicted as a typical film noir or rather neo-noir femme fatale. She recreates the typical trajectory, behavior and actions of a 'traditional' femme fatale, however, she is redeemed by the love of a man, Hercules, ending the story in marriage. Mittens in Bolt (2008) - the black cat whose life got an unfortunate turn, which made her turn into a sarcastic quasi-mafia Don of the New York animal underworld - is a very similar character to Meg. With her street-smart, wayward sarcasm Mittens seems to be a reworked/remade or further-developed Meg character, except for a femme fatalish sexuality. In Bolt, finally, we have a positive single mother figure (who is alive throughout the entire film and even stands up for themselves in the end by quitting the business and firing their agent) and a little girl who is an action hero. In the meantime, the animated film has several metanarrativistic references to, as well as criticism about, filmmaking, the entertainment business and the Hollywood 'machine' - also referring to Los Angeles as "the most terrifying place on Earth" (Howard and Williams 2008: $1 \mathrm{~h} 15 \mathrm{~min}$ ) while showing it from a spectacular view looking down at the city (probably) from the Mullholland Scenic Overlook. The film also comments on 'the average American' in the figure of Rhino, a hamster in a running ball living in the dream world of Bolt's TV show, who turns out to be much more than he first appears to be and proves to be a significant helper. Additionally, all this is done in a bright self-ironic as well as self-reflective manner that was not so characteristic of the Disney Company before, however, the hero of the story is Mittens and not Bolt. Without her, there would be no story and Bolt, the phony hero, would have simply died within a short period of time. It is Mittens who teaches him what a dog is and how dogs usually behave; just as well, it is her, who opens his eyes to the fact that he is not an actual hero, neither is his TV show real, but only pretence and acting. It is again the (seemingly) 'bad woman', who brings the story alive, yet, she is also domesticated by the end and her 'edge' is smoothed over.

Mulan (1998) and The Incredibles (2004) both offer the perfect combination of the defiant, aggressive and violent militant woman as well as the emotional, more traditional and family-centered forms of femininity while these women's intelligence and resourcefulness are always at the center of their actions. After all, Mulan becomes a celebrated and acknowledged national hero/heroine after 
saving her father, family, and eventually, her country. This story is really about a warrior woman called Fa Mulan, who is an integral part of Chinese culture and legends. In this adaptation, Mulan also has a 'kickass' granny who provides clear and insightful comments and criticism in an ironic manner - making her deeply subversive through these. For example, when she gives a 'lucky cricket' to Mulan because she thinks that Mulan can never make it on her own and declares that "you'll need more luck than I thought" (Bancroft and Cook 1998: 6 min) and with the help of the cricket "even you can't blow it" (Bancroft and Cook 1998: 8 $\mathrm{min}$ ), or when, at the end, seeing the 'man candy' captain coming for Mulan, she shouts: "sign me up for the next war" (Bancroft and Cook 1998: 1 h 20 min). In Mulan, we get the most subversive and explicit moments of, and comments on, gender-bending, trans-dressing, definitions of gender as well as gender performativity. For the first time, we have a girl dressed as a boy - being openly miserable about being a girl and the attached expectations knowing that it is not her calling to pursue a traditional feminine life - and while performing the role of a boy she makes everybody believe she is one. It is an astonishing moment in the film when, as an acknowledgement and appreciation of her actions and achievement, everybody bows to her. What is more, when returning home she offers her father the tokens of her victory to show that she saved the family honor, in response, her father throws all these away and claims that "the greatest gift and honor is having you for a daughter" (Bancroft and Cook 1998: 1 h 19 min). However in the end, she also gives up a position in the Emperor's Council for the love of a man, marriage and her home ending in a traditional way a very challenging and spectacular journey of gender subversion. In the meantime, Helen Parr/Elastigirl joins characteristics of the pragmatic mother figure who wears the trousers in the family, and the cool, girlishly stylish, yet always professional superhero/ine. Additionally, as a mother figure, she is/stays (surprisingly) alive and functioning throughout the story, what is more, she is much rather the head of the family, who saves everybody and solves all the problems, although, the final battle can be won only with the joint effort of the whole family. It is also slightly disheartening that the mother has the superpower of elasticity while the daughter (Violet) that of invisibility (and producing power shields). Finally, we have a superhero family and the female members of the family get superpowers that are quite in accordance with traditional femininity and not something challenging or exceptional. Nevertheless, these warrior women are outstanding characters with integrity and complexity.

In WALL-E (2008), there is EVE (Extraterrestrial Vegetation Evaluator) - coded as female -, who is a latest-development, professional robot, doing her job perfectly, even if it entails shooting others. She is a 'tough gal', who is sent to a postapocalyptic Earth that is trying to recover from an ecological catastrophe, to look for signs of life. She is again a complex character who is a professional soldier and warrior as well as (ironically) Gaia-like the Great Mother of Humankind and Life. In fact, she becomes the savior of the human race by receiving a living plant as a gift from WALL-E (Waste Allocation Load Lifter - Earth-Class) - coded as 
male (even if being a robot makes it pointless from a reproductive point of view) -, placing it into a cavity in her 'belly' (with a green flashing light showing 'I am pregnant' while she shuts down into an 'unconscious state of blessedness'), then she is carried back to Axiom, the spaceship where humans live by now. After this, humans decide to return to Earth and start a new life. Hence masculine and feminine traits are in perfect combination since here is a machine saving humans through acts of mothering as well as fighting as a warrior in a high-tech world. Additionally, the film is openly critical about people's irresponsible behavior concerning waste and pollution. It is especially striking and ironic to see the spectacle of the ruined Earth combined with the nostalgic and sentimental melodies of Hello Dolly (1969), a famous musical of a 'Golden Era'. The animated film also criticizes how idle and oversized people became while they do not even see and talk to each other in real life since they are constantly distracted by small screens right in from of their eyes as well as by giant screens in the distance.

Then, Disney tried to turn back to the 'old Magic Kingdom recipe' with a little twist, which did not really pay off. In Tangled (2010), Rapunzel is a rather athletic and resourceful figure while undoubtedly she turns into a fighter only accidentally with the help of a frying pan. Even if she can coerce a thief into taking her to see the much-desired lanterns, convince 'ruffians' to let her and her guide go unharmed, use her (magic golden) hair Trazan-like and heal with it while it glows, she is still a quite traditionally feminine girl who does not want to step out of line. Yet, she has a stepmother who greatly resembles the classical femme fatale-type of the Disney evil woman, Mother Gothel. She is a mature beauty and quite pretty considering that she is a several-hundred-year old witch who rejuvenates herself with Rapunzel's magic hair - that is why, she kidnapped the baby Rapunzel and keeps her hostage while concealing all this form her and acting as her real (slightly cold and distant) mother. Mother Gothel is mostly manipulative and cunning, however, she does not shy away from using real (even physical) violence when provoked, and she also kills a person in full view, Flynn Rider - even if it is not entirely shown how she does that, still, this happens in a Disney animated film. Nevertheless, the evil femme fatale still perishes as a punishment for her actions even in 2010 in the World of Disney, while the ingénue lives happily ever after with her (hopefully) reformed thief-turned-prince.

However, we finally arrive at the great turn in the history of Disney(/Pixar) women. The case of Brave (2012) proves how a film starring a masculinized heroine with outstanding skills in horse-riding, archery and sword-fighting can serve as a female empowerment narrative. It was considered to be a groundbreaking move on the part of Disney/Pixar that they actually created a heroine who is masculine in many respects, and is much rather a boy than a girl within her family as well as the first-born, hence, an heir/ess to the throne. She is a boy heroine as evidently she is in the status of a first-born boy within her family. Her depiction is also unconventional because she hardly ever behaves in a traditionally-conceived feminine way and almost always moves, walks and acts as men and boys do in general. We mostly see her in active and often dangerous physical situations, and 
with phallic objects in her hands. She is fighting with expertise and defeats men and bears. Here the mother-daughter relationship - a delicate and complicated issue usually not addressed by Disney creators - appears at the center of the story dressed up not in some idealized 'flurry, pink, cotton fluff', but presented as what it is: a bear fight. In a narrative offering a realist depiction of the psycho-dynamics of mother-daughter relationships, girl viewers - a key target group of Disney are likely to discover more than the tale of a girl with phallic objects in her hands behaving as a boy, but a female coming of age story in a tough, masculine world where women have to fight their way out of patriarchal values and start to reformulate them. Merida can defeat her male rivals (supposedly suitors) with ease in the memorable scene of the arching contest (where the young men compete for her hand) by ignoring markers of female/feminine beauty. In a symbolic act, she rips her beautiful bodice in order to pull the string of her bow properly and stands defiant with flowing hair while she defends her own right to her own hand thus winning her freedom. This symbolic act/event unfolds in a way that, first, she is bound in a corset and a tight, feminine dress (her head covered, since she is not a girl, but a soon-to-be-married young woman), and she first pulls a little hair out of the head cover to destroy the 'perfect' image, then, she competes for her own hand as the first-born in her family, while tearing her dress as well as accidentally wounding her face slightly causing a scar - one of the most important tokens of feminine beauty, and as we know: "[w]ithin patriarchy and allegory, 'beauty' is the essential quality of femaleness" (Craven 2002: 138). However, she is a woman warrior who does not plan a typical feminine or womanly life for herself, and does not shy away from fighting for it in every way. Merida's fully emancipated self is further strengthened in the climactic scene resembling an Oedipal conflict, as she (as the first-born 'son' and 'heir' of the family) stands confidently, bravely and fiercely (sword in hand) between her father (causing his fall) and the bear-turned mother figure shouting at him: "I will not let you kill my mother" (Andrews and Chapman 2012: $1 \mathrm{~h} 17$ mins). And in the end, she refuses to get married and rides away with her mother - as if the Disney writers and animators got inspiration from Angela Carter. It seems that real feminist empowerment is allowed for Disney heroines, or rather female heroes, not solely through masculine deeds of grandeur and violence but overcoming the stereotypes according to which self-fulfillment is achieved through the pursuit of beauty and finding a male partner. Merida manages to save her mother and unite her family through a joint masculine-feminine act: she is riding her horse while mending (sewing) the tapestry (that symbolizes family unity and her feminine activities) she cut with her sword previously; then, she defends her mother with her sword against her father, and, finally, covers her mother with the mended tapestry while crying and hugging her. Thus, the end is rather an androgynous closure.

The quest for a self-sufficient and balanced identity lies at the center of Frozen (2013), which, in my view, presents the most accomplished and complex violent woman figure of the Disney Universe in the character of Elsa. It is evident that she is the remake of Andersen's famous or rather notorious Snow Queen (an iconic 
cultural and literary archetype of a wicked woman) - who, by the way, hardly appears in the original Andersen tale written (supposedly) about her. In this original tale, she does not actually do anything evil, and it is, in fact, Gerda's quest and her story of development as well as trial, while she is the one who manages to save and rescue Kai. So, it is evidently a great step to present such an iconic, negative, violent female character, a femme fatale, as a positive - even if troubled and disturbed - figure and to make her a protagonist and not an antagonist. Unlike the Andersen-character, Elsa does not look or act like an evil sorcerer/sorceress, her creators at Disney foregrounded the psychopathology of her behavior and explored the traumatic side of her personality. As Amanda Hutchinson argued,

With her icy powers that reign over Frozen's town of Arendelle, Elsa's role, inspired by The Snow Queen fairy tale, was intended to be a villain. But after the Lopezes came to the script-writing team with Elsa's defining "Let It Go", they immediately gravitated to the song's positive message of selfworth and acceptance and tweaked the character to be a protagonist. That's what we call the power of music! (2014)

So, it seems to be evident that the creators, first, wanted to keep the wicked queen role for Elsa, thus the change in her characterization resulted from ongoing negotiation and as a result of willingness on the part of the makers to think her over and make her over. As we know, her song entitled "Let it go" won an Academy Award for "Best Achievement in Music Written for Motion Pictures, Original Song" (Awards for Frozen (2013), The Internet Movie Database) that turned out to be an "empowerment anthem" (Boxer 2014) all over the world (except for Hungary, due to such intolerable mistakes, like translating the key line with the very weighty words of "let it go" into "let it snow" butchering its message). During this song, Elsa comes to terms with herself, becomes a complex and full human being and makes the initial steps to put her past life, full of repression and compulsory self-constraining of her magic behind herself. The scene portrays her transformation into a woman who becomes acquainted with her body, and who no longer perceives it as a damnation to have magical abilities, in the meantime, she also understands her wishes, desires as well as her shortcomings while becomes aware of her powers, talents, abilities that she starts to learn to control. In a moment of symbolic self-realization she lets down her long blond hair and metamorphoses from a faint-hearted girl into a daring and self-confident woman. At the end of the song, she declares that "the perfect girl is gone" (Buck and Lee 2013: $34 \mathrm{~min}$ ), which is visually accentuated by her newly-found sexual awareness. It should also be noted, that she uses her magical powers for creation and not destruction for the first time: she 'gives birth' and creates a living being, a hilarious, and at the same time, compassionate snowman named Olaf - who might be a gay character considering his relationship with Sven, the reindeer. Elsa resembles Pinocchio's Blue Fairy not only in terms of physical appearance but also through this act of becoming a mother through magic: "[t]he Blue Fairy ... replaces the 
practice of giving birth with a swish of her wand. ... The Blue Fairy does become the mother in the end, albeit a covert one. With the Blue Fairy's character, Disney aimed to do away with the superstition that women can be "either attractive or serious"” (Brode 119 quoted in Bálint 2013).

While singing her powerful and transformative song, she changes from a virginal creature into a sexually-mature woman as well as comes into a full possession of her icy magic. Yet she must still learn to use that magic, a knowledge that will be gained in her tense and intense relationship with Anna, her sister. In this regard, Frozen (2013) deals with the psychological context of sister-sister relationships, an issue just as delicate as the mother-daughter relationship was in Brave (2012), and just as well, mostly not touched upon by Disney creators. The message of the Disney tale is spelled out as the conflict between the sisters is resolved: in Frozen (2013), the true love's kiss is replaced by the act of true love, self-sacrifice, for a sister - even if this means that Elsa allows Anna to save her and the kingdom with all the people in it. This act of true love, although, is to save Elza, Anna indirectly saves herself with it likewise, hence, not a man is needed to save her any more. This also makes Elsa realize how through love she can properly manage everything and control her magical powers. All this makes Anna the real hero and protagonist of the story. She is the one who sets out on a quest and solves all the problems, she is the one, who improves as the story develops, and she makes the story happen - in fact, similarly to Gerda in the original story, where, just as similarly, the protagonist is actually not Elsa/The Snow Queen. Additionally, even though there is the promise of a future marriage between Anna and Kristoff, the film closes with the two sisters holding each other by the arm while it is evident that Elsa, who is the queen, has no romantic entanglements at all and is free and independent.

It is also to be noted that Disney has been criticized for having 'love at first sight' relationships all the time which are, in fact, rather unrealistic and harmful considering real relationships and what these films teach children about femalemale love and bonding. As Litsa Renée Tanner et al. argue, "[i]n the majority of the [Disney] movies the couples fell in love, got married, and 'lived happily after.' The idea that love is 'easy' and requires no work is most clearly illustrated in Snow White and the Seven Dwarfs; Snow White manages to fall in love while sleeping" (Tanner et al. 2003: 364); they add that "[t]he idea that falling in love takes time appears to be a more recent development in animated movies" referring to the 1990s (Tanner et al. 2003: 365). It is a wonderful gesture of self-reflection and self-criticism that, in Frozen, it is repeated twice that 'love at first sight' does not work and we cannot marry someone, whom we have just met because we do not know the person: "You can't marry a man you have just met!" - declares Elsa (Buck and Lee 2013: min 26); "You got engaged to someone you met that day?! - asks Kristoff astonished (Buck and Lee 2013: 40 min). In addition, Prince Charming is also 'dethroned' as Hans turns out to be an evil figure, a real antagonist, and he, as the male love interest, is replaced by a 'real man', who actually has a job, works hard, knows how life works, has integrity, courage 
and perseverance, additionally, he is capable of meaningful relationships. What is more, during Kristoff's sleigh ride with Anna, the viewers (mostly children) also get a lesson in how love relationships work when you have to realize that your love might have disgusting or irritating bad habits, that you might do not like their family or other friends, and maybe, the size of his shoes might not be to your liking...

All in all, although Disney seems to be a rather unlikely candidate for giving us (some of) the most memorable and complex violent women in (mainstream) Hollywood, they have always excelled, as they still do, in this regard. From the Wicked Queen in Snow White and the Seven Dwarfs (1937) to Merida in Brave (2012), Elsa and Anna in Frozen (2013), Maleficent in Maleficent (2014), Judy Hopps and Bellwether in Zootopia (2016) or Moana and Te Fiti in Moana (2016), Disney created 'fully real' and well-rounded violent women and femmes fatales, who are great fighters and real warriors while being powerful, intelligent, and even sexual. Their herstories vary just like their reasons, methods as well as aims, yet, they are all complex, fully real women who are not afraid to act violently. Disney heroines have come a long way and transformed from passive, somnabulistic beauties into active and powerful agents of their own and others' destinies while absorbing into themselves the strong femme fatale characters of early Disney. Eventually, we could simply reassert Do Rozario's last claim that, while the Disney enterprise and kingdom is still a patriarchal world, it is greatly dependent on a princess (2004: 57), who is always in touch with the demands of the times.

\section{References}

Andrews, Mark and Chapman, Brenda (dir.) (2012) Brave. written by Brenda Chapman et al. Walt Disney Pictures and Pixar Animation Studios.

Awards for Frozen (2013) The Internet Movie Database. Accessed on 23 December 2015. http:// www.imdb.com/title/tt2294629/awards?ref =tt_ql 4

Bálint, Emma (2013) 'The representation of women in Walt Disney's productions in the studio era'. AMERICANA, E-Journal of American Studies in Hungary IX:2 (Fall). Accessed on 16 January 2016. http://americanaejournal.hu/vo19no2/balint

Bancroft, Tony and Barry Cook (dir.) (1998) Mulan. written by Robert D. San Souci et al. Walt Disney Pictures.

Bell, Elizabeth (1995) 'Somatexts at the Disney Shop'. In: Elizabeth Bell et al. (ed.) From Mouse to Mermaid. The Politics of Film, Gender and Culture. Bloomington: Indiana University Press, $107-124$.

Bird, Brad (dir.) (2004) The Incredibles. written by Brad Bird. Pixar Animation Studios and Walt Disney Pictures.

Boxer, Sarah (2014) 'Why are all the cartoon mothers dead?' The Atlantic July/August Issue. Accessed on 12 July 2014. http://www.theatlantic.com/magazine/archive/2014/07/why-are-all-thecartoon-mothers-dead/372270/

Brode, Douglas (2005) Multiculturalism and the Mouse: Race and Sex in Disney Entertainment. Austin: University of Texas Press.

Bronfen, Elisabeth (2004) 'Femme Fatale - Negotiations of Tragic Desire'. New Literary History $35,103-116$. 
Buck, Chris and Lee, Jennifer (dir.) (2013) Frozen. written by Jennifer Lee et al. Walt Disney Animation Studios and Walt Disney Pictures.

Clements, Ron (dir.) (1997) Hercules. written by Ron Clements et al. Walt Disney Pictures.

Clements, Ron (dir.) (1989) The Little Mermaid. written by John Musker et al. Walt Disney Pictures.

Clements, Ron et al (dir.) (2016) Moana. written by Jared Bush et al. Walt Disney Animation Studios.

Cottrell, William et al. (dir.) (1937) Snow White and the Seven Dwarfs. written by Ted Sears et al. Walt Disney Productions.

Craven, Allison (2002) 'Beauty and the belles: Discourses of feminism and femininity in Disneyland'. European Journal of Women's Studies 9(2), 123-142.

Cuomo, Chris (1995) 'Spinsters in sensible shoes'. In: Elizabeth Bell et al. (ed) From Mouse to Mermaid. The Politics of Film, Gender and Culture. Bloomington: Indiana University Press, 212-223.

Daniel, Robert L. (1987) American Women in the 20 $0^{\text {th }}$ Century. The Festival of Life. San Diego: Harcourt Brace Jovanovich Publishers.

Davis, Amy M. (2012) Good Girls \& Wicked Witches. Women in Disney's Feature Animation. New Barnet, Herts: John Libbey Publishing Ltd.

Dijkstra, Bram (1996) Evil Sisters. The Threat of Female Sexuality and the Cult of Manhood. New York: Alfred A. Knopf.

Do Rozario, Rebecca-Anne C. (2004) 'The princess and the magic kingdom: Beyond nostalgia, the function of the Disney drincess'. Women's Studies in Communication 27 (1) (Spring), 34-59. Accessed on 12 July 2014. http://www.uky.edu/ addesa01/documents/ThePrincessandtheMagicKingdom.pdf

Edwards, Leigh H. (1999) 'The United Colors of "Pocahontas": Synthetic miscegenation and Disney's multiculturalism'. Narrative 7(2), 'Multiculturalism and Narrative' (May), 147-168.

Feinman, Clarice (1994) Women in the Criminal Justice System. 3rd edition. Westport: Greenwood Publishing Group.

Ferguson, Norman (dir.) (1940) Fantasia . written by Joe Grant et al. Walt Disney Pictures.

Ferguson, Norman (dir.) (1940) Pinocchio. written by Ted Sears et al. Walt Disney Productions.

Gabriel, Mike (dir.) (1995) Pocahontas. written by Carl Binder et al. Walt Disney Pictures.

Geronimi, Clyde (dir.) (1961) One Hundred and One Dalmatians. written by Bill Peet et al. Walt Disney Productions.

Geronimi, Clyde (dir.) (1959) Sleeping Beauty. written by Erdman Penner et al. Walt Disney Productions.

Geronimi, Clyde (dir.) (1950) Cinderella . written by Bill Peet et al. Walt Disney Productions.

Gilbert, Sandra M. and Gubar, Susan (1980) The Madwoman in the Attic. New Haven: Yale University Press.

Greno, Nathan (dir.) (2010) Tangled. written by Dan Fogelman et al. Walt Disney Pictures.

Griffin, Sean (2000) Tinker Belles and Evil Queens: the Walt Disney Company from the Inside Out. New York: New York University Press.

Hall, Don and Chris Williams (dir.) (2014) Big Hero 6. written by Jordan Roberts et al. Walt Disney Animation Studios and Marvel Comics.

Harvey, Sylvia (1996) 'Woman's place: the absent family of film noir'. In: Kaplan, E. Ann (ed.) Women in Film Noir. London: BFI Publishing, 22-34.

Heller, Reinhold (1981) The Earthly Chimera and the Femme Fatale: Fear of Woman in Nineteenth-Century Art. Exhibition catalogue, May 20-June 21. The David and Alfred Smart Gallery, University of Chicago.

Howard, Byron and Chris Williams (dir.) (2008) Bolt. written by Dan Fogelman and Chris Williams. Walt Disney Pictures.

Howard, Byron and Chris Williams (dir.) (2016) Zootopia. written by Byron Howard et al. Walt Disney Pictures. 
Hutchinson, Amanda (2014) '5 things you didn't know about Disney's 'Frozen' soundtrack'. MetroLyrics 15 April. Accessed on 23 December 2015. http://www.metrolyrics.com/news-story5-things-you-didnt-know-about-disneys-frozen-soundtrack.html

Knobloch, Susan (2001) 'Sharon Stone's (an)aesthetic'. In: McCaughey, Martha and King, Neal (ed.) Reel Knockouts. Violent Women in the Movies. Austin: University of Texas Press, 124-143.

Ledger, Sally. (1997) The New Woman, Fiction and Feminism at the fin de siècle. Manchester: Manchester University Press.

Murphy, Patrick D. (1995) 'The whole wide world was scrubbed clean'. In: Bell, Elizabeth, et al. (ed.) From Mouse to Mermaid. The Politics of Film, Gender and Culture. Bloomington: Indiana University Press, 125-136.

Place, Janey (1996) 'Women in film noir'. In: Kaplan, E. Ann (ed.) Women in Film Noir. London: BFI Publishing, 35-67.

Rothman, William (2004) The "I" of the Camera, Essays in Film Criticism, History, and Aesthetics. Cambridge: Cambridge University Press.

Stanton, Andrew (dir.) (2008) WALL-E. written by Andrew Stanton et al. Walt Disney Pictures and Pixar Animation Studios.

Stevenson, Robert (dir.) (1964) Mary Poppins. written by Bill Walsh et al. Walt Disney Productions.

Stromberg, Robert (dir.) (2014) Maleficent. written by Linda Woolverton et al. Roth Films and Walt Disney Pictures.

Tanner, Litsa Renée et al. (2003) 'Images of couples and families in Disney feature-length animated films'. The American Journal of Family Therapy 31, 355-373.

Tóth, Zsófia Anna (2011) Merry Murderers: The Farcical (Re)Figuration of the Femme Fatale in Maurine Dallas Watkins' Chicago (1927) and its Various Adaptations. Newcastle upon Tyne: Cambridge Scholars Publishing.

Trousdale, Gary (dir.) (1991) Beauty and the Beast. written by Linda Woolverton. Walt Disney Pictures.

Trousdale, Gary (dir.) (1996) The Hunchback of Notre Dame. written by Tab Murphy et al. Walt Disney Pictures.

Zemeckis, Robert (dir.) (1988) Who Framed Roger Rabbit. written by Jeffrey Price et al. Touchstone Pictures and Walt Disney Feature Animation.

Zipes, Jack (2011) The Enchanted Screen. The Unknown History of Fairy-Tale Films. New York and London: Routledge.

ZsóFIa ANNA TóTH received her $\mathrm{PhD}$ in British and American literature and culture from the University of Szeged and is currently a junior assistant professor at the Department of American Studies, Institute of English and American Studies, University of Szeged. Her general research interests are film studies, cultural studies, gender studies, literary theory, humor theories, English and American literature, and American cinema. Her main research field is the representation of female aggression and violence in American literature and film. Her current research field is women's humor, especially the work(s) of Mae West.

Address: Zsófia Anna Tóth, PhD, Department of American Studies, Institute of English and American Studies, University of Szeged, Egyetem utca 2, 6722 Szeged, Hungary. [email: tothzsofianna@, gmail.com] 